Rev. Biol. Trop. 52(2): 363-370, 2004

www.ucr.ac.cr www.ots.ac.cr www.ots.duke.edu

\title{
A new species of Microphallus (Trematoda: Microphallidae) from Venezuela
}

\author{
M.T. Díaz ${ }^{1}$, A.K. Bashirullah*, 2 \& L.E. Hernández ${ }^{1}$ \\ Instituto de Investigaciones en Biomedicina y Ciencias Aplicadas, Universidad de Oriente, Cumana 6101, Venezuela \\ Instituto Oceanográfico de Venezuela, Universidad de Oriente, Cumana 6101, Venezuela \\ Corresponding author. Fax: 58-293-4301358; bashiru@udo.edu.ve \\ Received 20-II-2003. C Corrected 05-III-2003. Accepted 09-III-2003.
}

\begin{abstract}
During 1997-1999, a total of 94 crabs, Uca rapax were collected from La Sabana, La Ceiba and El Paujil, Sucre State, Venezuela. Of these 36 were infected with metacercariae. Two parasites were located in the abdominal muscles and one under the tissue of carapace and gonad. These metacercariae grew to adults in the following genera: Levinseniella, Microphallus and Maritrema, in the period of 2-5 days after feeding experimentally to the rat Rattus norvegicus, mice Mus musculus and duck Cairinia moschata. Specimens of the genus Microphallus were described herein as a new species M. sabanensis. The life cycle of M. sabanensis sp.nov. were studied experimentally using rat, mice and duck. All developmental stages and the adult are described. In addition, M. sabanensis was collected from wild birds Anas discors, Pluvialis squatarola, Butorides striatus, Egretta caerulea and Nycticorax violaceus from the same localities.
\end{abstract}

Key words: Microphallus sabanensis, digenetic trematode, Venezuela.

Adult worms of the family Microphallidae occur primarily as intestinal parasites of birds and mammals, while metacercariae are commonly found in decapod crustaceans. In each of the known microphallid life cycles reported to date, Xiphidiocercariae resembling cercariae ubiquita (Lebour, 1907) Lebour, 1912, have been shown to be produced by sporocysts developing in various prosobranch snails. Encysted metacercariae of this family are known to undergo extensive organogenesis in gastropod hosts, but more frequently they do so in arthropod intermediate host (Caveny and Etges 1971). Significant contributions to the knowledge of microphallid life histories have been made by Cable and Hunninen (1940), Stunkard (1957, 1958), James (1968), Caveny and Etges (1971) which illustrate the pattern of the life cycle. The objective of this study is to describe a new species of microphallids from Venezuela and some aspects of its life cycle.

\section{MATERIALS AND METHODS}

In examination of metacercaria fauna in crustacean, specially Uca rapax (Smith) in the localities of La Sabana, La Ceiba and El Paujil of the Cajigal district in Sucre State, Venezuela, during 1997-1999, 36 of the 94 crabs, U. rapax were found to be infected with three different types of encysted metacercariae, two of which were located in the abdominal muscles and the other under the carapace and in the digestive gland. All these cysts were fed to experimental hosts: rats Rattus norvegicus (Berkenhout), mice Mus musculus (L.) and duck Cairina moschata (L.) and found 3 species of adult microphallids trematodes in the small intestine, 2-5 days after feeding the cysts. Both rats and mice were collected from the biotery of the university and ducks were collected from locally reared farms. The trematodes were identified according to Deblock (1971) and Yamaguti (1971). 
Attempts to excyst all metacercariae in $0.75 \%$ saline at a room temperature of $26^{\circ} \mathrm{C}$ in a petri dish were unsuccessful, even with manual manipulation. Later, the cysts were placed in a $0.5 \%$ trypsin solution buffer at p.H 7.2 phosphate at room temperature for $4 \mathrm{~h}$. The encysted, excysted metacercariae and adult worms naturally and experimentally obtained were rinsed and studied alive. Examination of birds: Anas discors (L.), Pluvialis squatarola (L.), Butorides striatus (L.), Egretta caerulea (L.), Nycticorax violaceus (Gm.) in the study area were found to be natural hosts of Microphallus sp., which is described herein as new species, and its partial life cycle is illustrated. Birds were collected by traps and shooting. All adult worms from naturally infected birds and experimental animals and excysted metacercariae were stained in Semichon's aceto-carmine and mounted on slide in Canada balsam. All measurements of Microphallus given in the descriptions are in micrometers and drawings were made with the aid of camera lucida.

\section{RESULTS}

\section{Microphallus sabanensis sp. $\mathbf{n}$.} (Fig. 1A)

Three species of adult microphallids trematodes were collected in the small intestine of experimental hosts, 2-5 days after feeding the cysts. These trematodes were assigned to the genera: Levinseniella (Levinseniella) Stiles \& Hassal 1901, Maritrema Nicoll 1907, and Microphallus Ward 1901. Birds: Anas discors, Pluvialis squatarola, Butorides striatus, Egretta caerulea, Nycticorax violaceus in the study areas were found to be natural hosts of M. sabanensis sp.n. Laboratory reared rats $R$. norvegicus and mice $M$. musculus and commercially produced duckling A. discors (L.) were used as experimental hosts. These were starved for a day and allowed to eat infected crabs in the cage and in some cases carapaces were removed and crab muscles shreaded for easy consumption. All experimental hosts were found infected and the organisms belonging to the genus Microphallus were described as a new species herein.

Encysted Metacercariae (Fig. 1A): Descriptions based on 15 worms: Elliptical cysts, 292-297 long by 217-308 wide with wall, found in abdominal muscles of crabs, $U$. rapax, most frequently in the joints of $1 \mathrm{st}$ and 2 nd leg of abdomen. Cysts are easily recognized by their distinctive external thick wall, which is composed by two layers, thick, transparent and striated outer wall and the fibrous inner wall. Metacercariae are immature in the cyst and constantly change form and shape due to body movement. Body spinose, oral sucker measures 40-69 long by 45-69 wide, acetabulum, 34-67 long by 45-80 wide. Prepharynx visible when metacercaria is moving. Pharynx muscular, 21-34 long by 16-21 wide, followed by slightly sinuos oesophagus, 40-80 long by 5-10 wide, bifurcates in front of acetabulum, almost post equatorial. Seminal vesicle transversely extended in between acetabulum and intestinal bifurcation. Prostatic glandular cells well developed. Seminal vesicle unites with genital muscular papilla via a small spermatic duct. Testes symmetrical, 40-94 long by 67107 wide, situated on both lateral side of acetabulum, with visible small groups of sperms. Ovary, 26-45 long by 59-88 wide, more developed than testes, is located on right side of acetabulum. Some uterus loops visible at posterior part of body. Vitelline follicles 7-8, sometime 6, underneath the testes. Excretory bladder V-shaped, containing granules of different shapes, only 3 flame cells visible. Excretory pore terminal.

Excysted metacercariae (Fig. 1B): Descriptions based on 20 worms: Metacercariae recovered from abdominal muscles of $U$. rapax did not excyst spontaneously, even with manual manipulation, successful excystment required emersion in $0.5 \%$ trypsin solution buffered at $\mathrm{pH} 7.2$ at a room temperature for $4 \mathrm{~h}$. The excysted metacercariae look similar to adults, except for lack of gonadal development and presence of eggs. Body pyriform, 

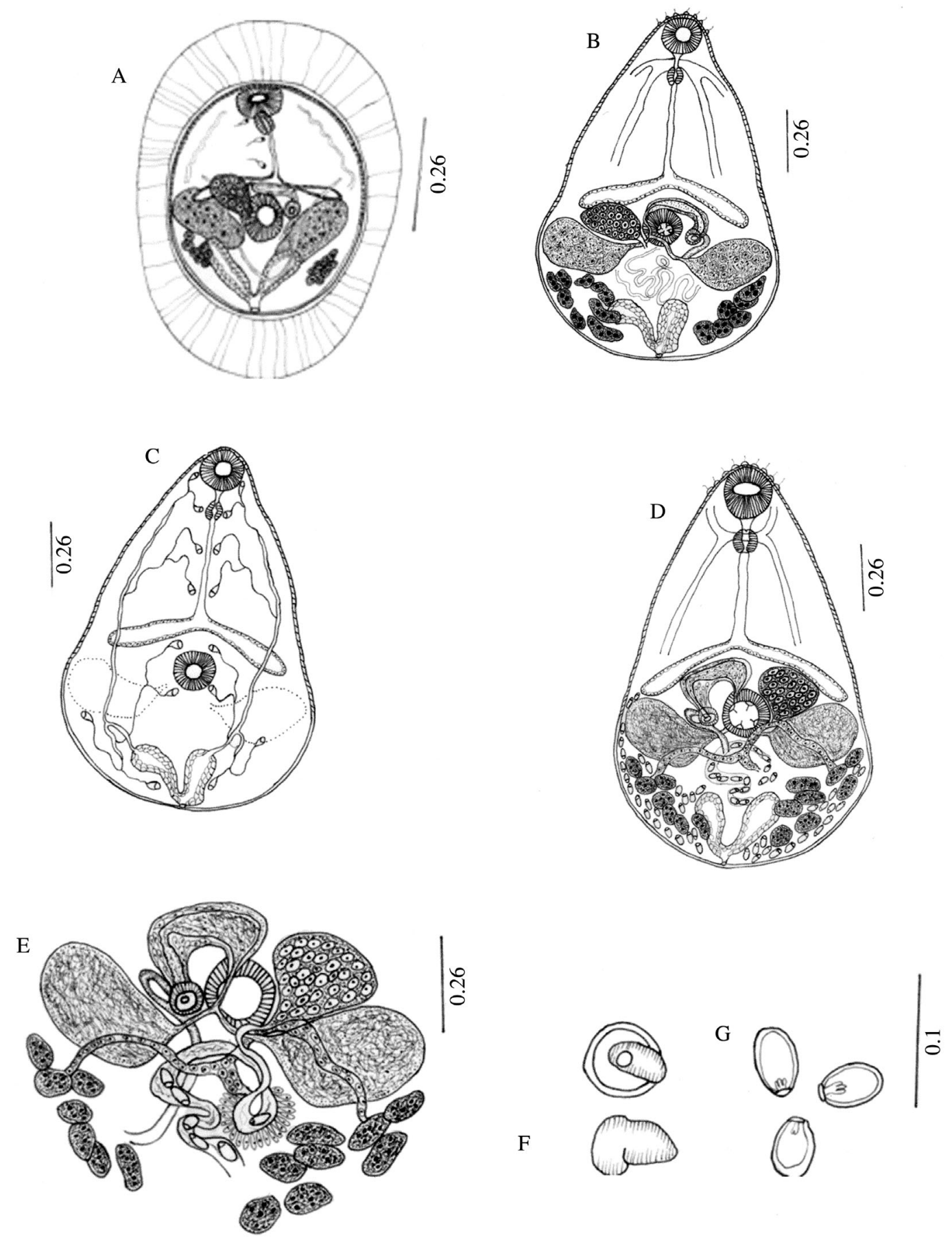

Fig. 1. Microphallus sabanensis sp. n. A. Encysted metacercaria. B. Excysted metacercaria. C. Excysted metacercaria showing protonephridial system. D. Adult collected from experimental definitive host. E. Male and female reproductive systems. F. Genital atrium, genital pore and male genital papilla. G. Embryonated eggs. 
215-378 long by 121-156 wide at testicular level. Tegument spinose, extending to ovary level. Nervous system consists of one cerebral commissure at pharynx level with posterior and lateral nerves, lateral one short and posterior one extends to caecal bifurcation. Oral sucker terminal, 51-56 long by 48-51 wide, prepharynx short, 8-13, pharynx muscular with 4 frontal lobules, 29-32 long by 16- 29 wide. Oesophagus $69-115$ long by $8-10$ wide, delicate, splitting in front of acetabulum in two intestinal caeca. Acetabulum, 45-53 long by 43-51 wide, possessing 4 sensorial papillae at its openings. Testes symmetrical, 48-67 long by 67-112 wide, located on each side of acetabulum. Efferent duct emerges from midlateral margin of each testis to mid acetabulum where the two unite and form a short vas deferens which enters into posterior part of seminal vesicle. Pars Prostatica well developed. Seminal vesicle and prostatic complex are covered by fine membrane. Genital atrium situated on left side of acetabulum, surrounded entirely by male genital papilla, 21-24 long by 16-26 wide. Genital pore opens at the side of opening of sperm duct. Ovary smooth, 40-45 long by 59-72 wide, located at the side of acetabulum and above right testis. Laurer's canal present. Mehlis's gland surrounds ootype. Uterus in the form of loops between testes and excretory vesicle. Metraterm somewhat sinous, penetrate from side of genital atrium and opens through female genital pore into genital atrium. Eggs absent. Vitelline glandular cells are arranged in two groups, one with 8 follicles on left and 7 on right but occasionally 6. Principal vitelline duct emerges from vitelline reservoir and unite with oviduct. Protonephridial system (Fig. 1C) constitutes by one V-shaped excretory vesicle. Excretory ducts open from the anterior part of excretory vesicle, which divides into anterior and posterior excretory ducts. Flame cell formula: $2\{(2$ $+2+2)+(2)\}=16$. Excretory pore terminal.

Experimental Infection: First experiment, 2 rats and 2 mice were each fed with 3 infected crabs and necropsied after 4-5 days and 128 gravid $M$. sabanensis were recovered from small intestine. A second group of 2 mice were each fed 2 infected crabs and 38 adult worms were recovered from the small intestine 5 days after experiment. At the same time, a duckling was fed 10 cysts and one adult $M$. sabanensis was recovered 5 days after the feeding. All adult worms recovered from the experimental animals are the same as those taken from naturally infected birds in the same localities.

Adult worms (Fig. 1D): Description based on 15 whole mounted and 5 live worms collected from experimental animals): Body pyriform, 393-555 long by 212-343 in maximum width at testicular level. Tegument spinose, to the level of intestinal caeca. Oral sucker terminal, 45-64 long by 51-67 wide, followed by a short prepharynx, 5-24 long by 5-10 wide, and pharynx muscular, well developed, 24-37 long by 16-32 wide, and bears 4 frontal lobules. Oesophagus same length as intestinal caeca, 59-123 long by 5-10 wide. Acetabulum, 45-67 long by 48-67 wide. Nervous system similar to that of metacercariae. Testes symmetrical, 43-80 long by $80-212$ wide, laterally elongate, Cirrus sac absent. Seminal vesicle oval, 67-107 long by 32-69 wide, preacetabular in position, filled with sperm. Seminal vesicle, sperm duct and prostate complex are surrounded by a fine membrane and sperm duct ending in small male genital papilla measuring 16-29 X 18-24 (Fig. 1E - 1F) which opens on the side of genital pore. Male genital cirrus everted in some cases, 16-24 long by 18-24 wide. The female reproductive system is composed of a ovary, 3775 long by 53-86 wide, oval, transversely elongated, antero-lateral to acetabulum, contiguous or immediately anterior to right testis. Oviduct emerges from mid posterior part of ovary and extends posteriorly receiving principal vitelline and seminal receptacle ducts, which unite with ootype, surrounded by Mehlis's gland. Laurer's canal observed only in live worm. Uterus originate from distal portion of ootype, occupying post-testicular region, finishing in metraterm which open at the genital pore. Eggs, embryonated, 18-21 long by 8-10 wide (Fig. 1G). Vitellaria in two lateral groups of follicles numbering 8 on the right and 7 on the 
left. Vitelline ducts meets below the Mehlis's gland between the testes, to form vitelline reservoir. Excretory vesicle V shaped, relatively large, flame cells same as metacercariae. Excretory pore terminal.

Type hosts: Natural definitive hosts: Anas discors, Pluvialis squatarola, Butorides striatus, Egretta caerulea, Nycticorax violaceus.

Experimental hosts: Mus musculus, Rattus norvegicus and Cairina moschata; Second intermediate hosts: Uca rapax; First intermediate host unknown.

Type localities: La Sabana, La Ceiba, El Paujil, Cajigal District, Sucre State, Venezuela.

Site of infection: Adults in small intestine and metacercariae in abdominal muscles and muscles of the bases of the legs.

Prevalence: $100 \%$ in natural avian hosts and $38.3 \%$ in $U$. rapax.

Etymology: Species name is after the locality La Sabana.

Holotype: Adult is deposited in the Parasitological collections of Institute of Biomedicine and Applied Sciences, Universidad de Oriente, Cumana, Venezuela, IIBCA No. 1224,

Paratype: IIBCA No.1225, in the above mentioned collections.

\section{DISCUSSION}

The first larval microphallid was described by McIntosh (1865) in Scotland, from the marine crabs, Carcinus maenas and Cancer pagurus. Cable and Hunninen (1940) described the first detailed accounts of an experimental life cycle for the genus Microphallus for $M$. nicolli of the family Microphallidae. The basic developmental pattern for this species involved sporocyst development in the prosobranch snail, Bittium alternatum, release of Ubiquita cercariae, metacercarial formation in the crustacean, Callinectes sapidus, and their rapid attainment of sexual maturity in intestine of the gull, Larus argentatus. This pattern was confirmed by a number of workers for a variety of other microphallid species as well as in the present study, where the second intermediate host was collected and the metacercariae was experimentally fed to 3 different experimental hosts. As with other microphallines, M. sabanensis n.sp. mature rapidly and live in the definitive host for only a short period, and rat, mice and duck have been used as definitive experimental hosts. Sogandares-Bernal (1965) used white mouse as an experimental definite host, and species in $M$. opacus use turtle and fish as definitive host (Rausch 1946). Most studies reported that microphallids mature in birds and mammals.

Caveny and Etges (1971) tended to suggest that there was a high probability of the life history of $M$. opacus being completed without involvement of a vertebrate host; in spite of earlier record of occurring $M$. opacus in seven fish species (VanCleave and Mueller 1934; Strandine 1943), two turtle species (Rausch 1946) and two mammalian hosts (Baer 1943 and Rausch 1946). They regard these occurrence as incidental rather than extremely obligate parasitism. The present authors do not accept the hypothesis as they collected three different microphallids trematodes, Levinseniella, Maritrema and Microphallus sabanensis n.sp. from small intestine of rat, mice and duck, 2-5 days after feeding metacercariae. In addition, M. sabanensis were collected from the small intestine of five wild bird species in the present study areas. Caveny and Etges (1971) reported the extremely rapid excystment of $M$. opacus suggesting that it was due to the endogenous production of histolytic agents by the worm, rather than host derived enzymes. We could not achieve excystment of $M$. sabanensis sp.n. in normal saline for $6 \mathrm{~h}$. and it was required $4 \mathrm{~h}$ or more in $0.5 \%$ trypsin solution. On the basis of the present results, we believe that Microphallus sabanensis sp.n. require a bird or mammalian definitive hosts for completing their life cycle.

Following the classification of Deblock (1971) and Yamaguti (1971), the species described herein fits into the genus Microphallus. The genus was created by Ward (1901) and its metacercariae was found in the crustaceans. M. sabanensis sp.n. is closely 
similar to $M$. similis and $M$. limuli, but differs significantly from both species (Table 1). The cysts of $M$. similis are found in the connective tissue of the digestive glands in Carcinus maenus, while the new species are never found in these tissues but only in abdominal muscles and muscles of the base of the legs of the $U$. rapax. The cyst walls are equal in $M$. similis but external cyst wall is striated and 4 times thicker in M. sabanensis. The stylet of the cercariae is visible for long time in encysted metacercariae of $M$. similis while it is absent in M. sabanensis. The male papilla of $M$. similis measures 38- 58 in diameter and 12- 14 long which almost fills the genital atrium while $M$. sabanensis is smaller, measuring 16- 24 in diameter and 18-24 long. In addition, $M$. similis differs from $M$. sabanensis in size and shape of body and eggs.

M. sabanensis sp.n. differs from $M$. limuli in the structure and size of the male papilla which is almost half the size of the later, measures 6-7.5 in diameter and 12-14 long. In front of the digestive caeca the body is filled with minute, unicellular glands in $M$. limuli which is absent in M. sabanensis. Oral sucker and acetabulum of both metacercaria and the adults of $M$. sabanensis possess sensorial papilla, which are absent in $M$. limuli. Muscular pharynx of $M$. sabanensis bears 4 frontal lobules which are absent in M. limuli. The vitellaria in $M$. limuli are large, compact mass of lobed glands, located below and behind the testes on each side, while it is

TABLE 1

Comparison of three species of Microphallus (All measurements are in mm.)

\begin{tabular}{|c|c|c|c|}
\hline Characteristics & M. similis & M. limuli & M. sabanensis sp.n \\
\hline Body Length & $0.36-0.7$ & $0.26-0.40$ & $0.393-0.555$ \\
\hline Body Width & $0.22-0.36$ & $0.15-0.20$ & $0.212-0.343$ \\
\hline Acetabulum & $0.048-0.065$ & $0.029-0.35$ & $0.45-0.067$ \\
\hline Oral sucker & $0.05-0.065$ & $0.035-0.045$ & $0.045-0.065$ \\
\hline Pharynx & $0.02-0.03$ & $0.017-0.21$ & $\begin{array}{l}\text { Mascular, thicker, } 0.024-0.037 \\
\text { x } 0.016-0.032 \text {, bears } 4 \text { frontal lobules }\end{array}$ \\
\hline Oesophagus & Long, longer than caeca & $0.1-0.13$ & $0.059-0.123 \times 0.005-0.01$ \\
\hline Ovary & $0.10-0.16 \times 0.06-0.09$ & $0.06-0.065 \times 0.036-0.045$ & $0.037-0.075 \times 0.053-0.086$ \\
\hline Egg & $0.022-0.27 \times 0.011-0.012$ & $0.016-0.02 \times 0.009-0.011$ & $0.018-0.021 \times 0.008-0.010$ \\
\hline Testes & $0.10-0.16 \times 0.06-0.09$ & Lateral, 0.05-0.065 & $0.043-0.08 \times 0.08-0.212$ \\
\hline Male papilla & $0.038-0.058$ & $0.06-0.0075$ & $0.016-0.024 \times 0.018-0.024$ \\
\hline Flame cell formula & $2\{(2+2)+(2+2)\}$ & $2\{(2+2)+(2+2)\}$ & $2\{(2+2+2)+(2)\}$ \\
\hline Exptl.definitive host & Gulls & Mice \& Hamsters & Ducks, Mice and Rat \\
\hline First Int. host & Snails (Littorina) & Unknown & Unknown \\
\hline $2^{\text {nd }}$ Int. host & Crabs, Carcinus maenas & Limulus polyphemus & Uca rapax \\
\hline Habitat of cysts & $\begin{array}{l}\text { Tissues of whole body,heavily } \\
\text { in digestive glands }\end{array}$ & $\begin{array}{l}\text { Connective tissues of digestive } \\
\text { glands and eyes }\end{array}$ & $\begin{array}{l}\text { Abdominal muscles and heavily } \\
\text { on joints of legs }\end{array}$ \\
\hline $\begin{array}{l}\text { Seminal vesicle \& } \\
\text { Prostatic complex }\end{array}$ & Free in the parenchyma & Free in the parenchyma & Covered with a fine membrane \\
\hline
\end{tabular}


composed of 2 internal groups of follicles numbering 8 on the right side and 7 on the left, reaching up to the posterior part of the body in $M$. sabanensis sp.n. In addition, Limulus polyphe$m u s$, the second intermediate host of M. limuli is far different phylogenetically from U. rapax.

\section{RESUMEN}

Durante 1997-1999, se recolectaron en La Sabana, La Ceiba y El Paujil del Distrito Cajigal, Estado Sucre, Venezuela, un total de 94 cangrejos Uca rapax, 36 de ellos estaban parasitados con tres especies de metacercarias de digéneos. Dos de ellos localizados en la musculatura del abdomen y una en el tejido que recubre internamente el caparazón y las gónadas. Estas metacercarias fueron dadas como alimento a ratones Mus musculus, ratas Rattus norvegicus, y patos Cairina moschata y tres genéros de microfálidos, Levinseniella, Microphallus y Maritrema fueron recuperados del intestino delgado de estos animales después de 2-5 días de la infección. Especimenes del genero Microphallus de este estudio se describen como Microphallus sabanensis sp.n. Se estudió experimentalmente los aspectos de ciclo vida de la especie, utilizando ratas, ratones y patos. Se describen todas las estapas larvales y los adultos. Además, $M$. sabanensis se encuentra naturalmente en las aves: Anas discors, Pluvialis squatarola, Butorides striatus, Egretta caerulea y Nycticorax violaceus.

\section{REFERENCES}

Baer, J.G. 1943. Les trematodes parasites musaraigne deau, Neomys fodiens (Schreb.). Bull. Soc. Neuchatel. Sci. Nat. 68: 33-84.

Cable, R.M. \& A.V. Hunninen. 1940. Studies on the life history of Spelotrema nicolli (Trematoda: Microphallidae) with a description of a new microphallid cercaria. Biol. Bull. 78: 136-157.
Caveny, B.A. \& F.J. Etges. 1971. Life history studies of Microphallus opacus (Trematoda: Microphallidae). J. Parasitol. 57: 1215-1221.

Deblock, S. 1971. Contribution a étude des Microphallidae Travassos,1920 XXIV. Tentative de phylogénie et de taxonomie Bull. Mus. Nat. Hist. Natur. 7: 359-468.

James, B.L. 1968. Studies on the life cycle of Microphallus pygmaeus Levinsen, 1881 (Trematoda: Microphallidae). J. Nat. Hist. 2: 155-172.

McIntosh, W.C. 1865. The trematode larvae and Ascaris of the Carcinus maenas. Quar. J. Micr. Sci. ns 5: 201204.

Rausch, R. 1946. The racoon, a new host for Microphallus sp. with additional notes on M. ovatus from turtles. J. Parasitol. 32: 208-209.

Sogandares-Bernal, F. 1965. Parasites from Lousiana crayfishes Tulane Stud Zool 12: 79-85.

Strandine, E.J. 1943. Variations in Microphallus, a genus of trematodes from fishes of Lake Lelanau, Michigan. Tr. Am. Micr. Soc. 62: 293-300.

Stunkard, H.W. 1957. The morphology and life history of the digenetic trematode, Microphallus similis (Jagerskiold, 1900) Baer, 1943. Biol. Bull. 112: 254-266.

Stunkard, H.W. 1958. The morphology and life history of Levinseniella minuta (Trematoda: Microphallidae). J. Parasitol. 44: 225-230.

VanCleave, H.J. \& J.F. Mueller. 1934. Parasites of Oneida Lake fishes III. A biological and ecological survey of the worm parasites. Roosevelt Wild Life Ann. 3: 161-334.

Ward, H.B. 1901. Notes on the parasites of lake fish III. On the structure of the copulatory organs in Microphallus nov.gen. Tr. Amer. Micr. Soc. 22: 175187.

Yamaguti, S. 1971. Synopsis of digenetic trematodes of vertebrates. Keigaku, Tokyo, I-II. 1074 p. 
